\title{
Iron loading and the liver: the effect on regeneration after partial hepatectomy
}

\author{
M. C. BRAIN \\ From the Departments of Haematology and Medicine, Postgraduate Medical School, London
}

EDITORIAL SYNOPSIS The gain in weight and incidence of mitosis of the posterior lobes of ironloaded and control rats are compared following partial hepatectomy. The percentage gain in weight of the regenerating livers over the first 72 hours was similar in the two groups, but at 11 days and 12 weeks growth of the iron-loaded livers was less than that of the controls. An increased incidence of mitosis was found in the iron-loaded rats, both before and after partial hepatectomy.

The relationship between the presence of excessive amounts of iron in the liver and the development of cirrhosis is incompletely understood. It has long been recognized that idiopathic haemochromatosis is a familial disorder (Sheldon, 1935; Lawrence, 1935), and more detailed studies have suggested that heterozygote carriers of the gene may have hepatic siderosis (Williams, Scheuer, and Sherlock, 1962). Although it is possible that the homozygous individuals may have a greater tendency to develop the full clinical syndrome (Williams et al., 1962), it is equally likely that alcoholism or nutritional deficiencies may be responsible for the development of the cirrhosis (Sheldon, 1935; Finch and Finch, 1955; Bothwell, Cohen, Abrahams, and Perold, 1959; MacDonald and Mallory, 1960). The distinction between idiopathic haemochromatosis and haemosiderosis is regarded by some workers as being clear cut (Cappell, Hutchison, and Jowett, 1957), but others have suggested that excessive iron absorption or repeated blood transfusion may, in association with chronic anaemia, alcoholism, or nutritional deficiencies, lead to a condition which is clinically and pathologically indistinguishable from idiopathic haemochromatosis (Schwartz and Blumenthal, 1948; Aufderheide, Horns, and Goldish, 1953; MacDonald and Mallory, 1960; MacDonald, 1963).

Attempts to produce cirrhosis of the liver in animals by the administration of excessive amounts of iron in the diet or parenterally have failed (Rous and Oliver, 1918; Cappell, 1930; Polson, 1933; Brown, Moore, Reynfarje, and Smith, 1950; Nissim, 1953; Rather, 1956; Golberg, Smith, and Martin, 1957). But although cirrhosis cannot be induced there is evidence that the presence of large amounts of iron causes a reduction in the activity of certain enzymes, and that the damaging effect of the iron may be enhanced, and cirrhosis may rapidly ensue if an iron load is accompanied by other hepatotoxic factors (MacDonald, 1960; Golberg and Smith, 1960; Witzleben and Chaffey, 1962).

It seems unlikely that the degree of siderosis of the liver is solely responsible for the development of cirrhosis in man. The animal experiments suggest that the toxic effects of iron on the liver may only become manifest if the liver is subjected to the additional 'stress' of a dietary deficiency or of a hepatotoxic agent. An alternative means of subjecting the liver to stress is to remove two-thirds of the liver by partial hepatectomy or by infarction. The ability of the remaining liver to regenerate can then be studied. Using this method, Weinbren, Fitschen, and Cohen (1960) have shown that the effect of irradiation of the liver only becomes apparent when the irradiated lobe is made to regenerate.

It was considered that additional information might be obtained on the toxic effect of iron on the liver if the ability of an iron-loaded liver to regenerate was compared with that of a normal liver. Iron-loaded and control rats have been subjected to partial hepatectomy. The growth and incidence af mitosis in the regenerating lobes of the liver have been compared at varying times after the operation.

\section{MATERIALS AND METHODS}

RATS Female black and white hooded rats bred in our laboratories and weighing 90 to $150 \mathrm{~g}$. were fed a normal diet of Research rat cubes.

IRON LOADING Iron-dextran (Imferon) was administered in a dose of $7.5 \mathrm{mg}$. per $100 \mathrm{~g}$. body weight by injection 
into alternate hind limbs three times weekly as described by Golberg et al. (1957). Sixteen doses were given to the iron-loaded animals, a total of $120 \mathrm{mg}$. of iron per $100 \mathrm{~g}$. body weight. Rats of the same age and sex served as controls and received no injections.

PARTIAL HEPATECTOMY The anterior two lobes of the liver were removed under ether anaesthesia by the method of Higgins and Anderson (1931). The operation was performed on 42 iron-loaded rats 12 to 16 weeks after the commencement of the iron dextran injections and on 54 control rats. The experiments were so timed that the second operation for removal of the regenerating posterior lobes of the liver was carried out between 7 p.m. and 10 p.m. Care was taken at the second operation to clamp the portal vein before dividing the hepatic vein to prevent the accumulation of blood in the liver.

WEIGHING Immediately after removal the lobes of the liver were blotted to remove excess blood and weighed in a watch glass of known weight. After removal of a portion for histological examination the remaining liver was in most experiments reweighed and placed in an oven at $105^{\circ} \mathrm{C}$. for 15 hours; after cooling the specimen was weighed again and the dry weight obtained. Retention in the oven for more than 15 hours did not cause any further reduction in weight.

HISTOLOGY Material for histological examination was processed by routine techniques, sections were stained with haematoxylin and eosin, and by Perls's reaction for iron.

The incidence of mitosis was expressed per 1,000 cells after examination of 200 high-power fields (objective $\times 40$, ocular $\times 8$ ) using a square ocular limiting a field $0 \cdot 15 \mathrm{~mm}$. edge. The total number of cells was counted in every tenth field. In this way a total of 4,000 to 7,000 cells were examined in each section.

EXPERIMENTAL PROCEDURE Partial hepatectomy was immediately followed by the removal of the posterior lobes in 10 iron-loaded rats and 22 control rats. The anterior and posterior lobes were weighed separately and the ratio of the weight of the anterior lobes to the total liver was determined.

Partial hepatectomy was carried out in groups of five or six iron-loaded and control rats which were killed 24 , $29,48,72$, and 264 hours afterwards. In each experiment the iron-loaded and control rats were operated on in random order and the second operation was always performed within five minutes of the stated time. Four iron-loaded and three control rats were killed 12 weeks after partial hepatectomy.

\section{RESULTS}

EFFECT OF IRON LOAD The rate of growth of the rats was unaffected by the iron-dextran injections, confirming the findings of Golberg et al. (1957), and at the time of partial hepatectomy the mean weight of the iron-loaded rats, $187 \cdot 8$ g. S.E. $\pm 3 \cdot 5$, was not significantly different from that of the control rats, 194.0 g. S.E. $\pm 4.8(\mathrm{t}=1.04 \mathrm{P}>0.3)$.

The iron load is accompanied by an increase in weight of the liver (Golberg et al., 1957). In 22 control rats the mean weight of the liver was $3.63 \mathrm{~g}$. \pm 0.011 per $100 \mathrm{~g}$. body weight, whereas in 10 iron-loaded rats the mean weight of total liver was $4.78 \mathrm{~g}$. \pm 0.012 per $100 \mathrm{~g}$. body weight. The increase in weight affected the anterior and posterior lobes equally. The ratio of the total weight of the liver to the weight of the resected anterior lobes in 10 iron-loaded rats was $1.66 \pm 0.055$ and in 22 control rats $1.64 \pm 0.058$; the difference between the means was not significant $(\mathrm{t}= \pm 0.94: 0.4$ $>\mathbf{P}>0.3)$. These ratios are similar to findings of Harkness (1952) in black and white rats. A factor of 1.645 was derived from the mean of the two groups, and this was used to estimate the total weight of the liver at the time of operation from the weight of the anterior lobe resected, the weight of the posterior lobes being obtained by subtraction. The weight of the remaining posterior lobes has been calculated in this manner (Table I).

EFFECT OF PARTIAL HEPATECTOMY The operation was equally well tolerated by iron-loaded and control rats, both groups showing comparable changes in body weight, apart from one iron-loaded rat which was found to have a lung infection and was excluded from the series.

Increase in weight of posterior lobe In view of the difference in weights of the livers in the two groups a direct comparison of the changes in weight of the posterior lobes following partial hepatectomy cannot be made. In Table I the mean gain in weight of the posterior lobes at the various times is given in grams and as the percentage of the initial estimated weight. The percentage gain in weight of the posterior lobes was similar in the iron-loaded and control animals at 24, 48, and 72 hours. At 11 days (264 hours) the percentage gain in weight of the posterior lobes of the control rats $(141.6 \pm 7 \cdot 7)$ was significantly greater than that of the iron-loaded rats $(106.1 \pm 8.8)(\mathrm{t}= \pm 8.6 \mathrm{P}<0.001)$. However, at this time the weights of the posterior lobes of the two groups did not differ significantly (iron-loaded $6.73 \mathrm{~g}$. \pm 0.45 , control 6.80 g. \pm 0.81 ). By 12 weeks the difference in growth appeared more marked, but the numbers of rats in each group were too small for a statistically significant difference to be established.

Regeneration of the liver is, as many workers have shown, accompanied by an increase in water content of the liver, as reflected by a decrease in the dry weight as against the wet weight. In Table II the ratio of the dry weight to wet weights of the resected anterior lobes and posterior lobes from rats killed 
TABLE I

\begin{tabular}{|c|c|c|c|c|c|c|c|}
\hline \multirow[b]{2}{*}{ Group } & \multicolumn{6}{|c|}{ CHANGE IN WEIGHT OF POSTERIOR LOBES AFTER PARTIAL HEPATECTOMY } & \multirow[b]{2}{*}{ Gain $(\%)$} \\
\hline & $\begin{array}{l}\text { Time Killed } \\
(\mathrm{hr} .)\end{array}$ & No. of Rats & $\begin{array}{l}\text { Body Weight } \\
\text { (g.) }\end{array}$ & $\begin{array}{l}\text { Estimated Weight } \\
\text { of Posterior } \\
\text { Lobes }(\mathrm{g} .)\end{array}$ & $\begin{array}{l}\text { Final Weight of } \\
\text { Posterior Lobes } \\
\text { (g.) }\end{array}$ & Gain (g.) & \\
\hline $\begin{array}{l}\text { Iron-loaded } \\
\text { Control } \\
\text { Iron-loaded } \\
\text { Control } \\
\text { Iron-loaded } \\
\text { Control } \\
\text { Iron-loaded } \\
\text { Control } \\
\text { Iron-loaded } \\
\text { Control } \\
\text { Iron-loaded } \\
\text { Control }\end{array}$ & $\begin{array}{l}24 \\
29 \\
48 \\
72 \\
264 \\
12 \text { weeks }\end{array}$ & $\begin{array}{l}5 \\
6 \\
5 \\
6 \\
6 \\
5 \\
6 \\
6 \\
5 \\
6 \\
4 \\
3\end{array}$ & $\begin{array}{l}191 \pm 6.2 \\
190 \pm 5.5 \\
184 \pm 2.6 \\
184 \pm 3.0 \\
190 \pm 9.6 \\
205 \pm 9.8 \\
184 \pm 3.2 \\
176 \pm 3.9 \\
192 \pm 12.1 \\
203 \pm 5.0 \\
194 \pm 9.1 \\
214 \pm 13.3\end{array}$ & $\begin{array}{l}3.59 \pm 0.09 \\
2.55 \pm 0.13 \\
3.77 \pm 0.13 \\
2.67 \pm 0.13 \\
3.66 \pm 0.11 \\
3.02 \pm 0.11 \\
3.33 \pm 0.32 \\
2.68 \pm 0.28 \\
3.24 \pm 0.11 \\
2.81 \pm 0.29 \\
3.61 \pm 0.40 \\
2.85 \pm 0.32\end{array}$ & $\begin{array}{l}4.81 \pm 0.29 \\
3.35 \pm 0.12 \\
5.49 \pm 0.25 \\
3.94 \pm 0.15 \\
5.95 \pm 0.22 \\
4.94 \pm 0.11 \\
6.38 \pm 0.33 \\
5.05 \pm 0.39 \\
6.73 \pm 0.45 \\
6.80 \pm 0.81 \\
8.28 \pm 0.20 \\
9.03 \pm 0.81\end{array}$ & $\begin{array}{l}1.02 \pm 0.36 \\
0.80 \pm 0.13 \\
1.72 \pm 0.83 \\
1.46 \pm 0.09 \\
2.28 \pm 0.57 \\
1.91 \pm 0.53 \\
3.03 \pm 0.34 \\
2.36 \pm 0.39 \\
3.49 \pm 0.52 \\
3.99 \pm 0.62 \\
4.65 \pm 0.37 \\
6.18 \pm 0.90\end{array}$ & $\begin{array}{r}33.8 \pm 4.7 \\
31.6 \pm 5.5 \\
45.5 \pm 4.6 \\
55.4 \pm 4.4 \\
62.4 \pm 6.9 \\
63.6 \pm 2.4 \\
91.1 \pm 6.4 \\
89.1 \pm 7.0 \\
106.1 \pm 8.8 \\
141.6 \pm 7.7 \\
134 \pm 21.2 \\
220 \pm 33.4\end{array}$ \\
\hline
\end{tabular}

TABLE II

WATER CONTENT OF RAT LIVER BEFORE AND AFTER PARTIAL HEPATECTOMY ${ }^{1}$

\begin{tabular}{|c|c|c|c|c|c|c|c|c|c|c|}
\hline \multirow{2}{*}{$\begin{array}{l}\text { Lobes } \\
\text { Time }(h r .) \\
\text { Group }\end{array}$} & \multicolumn{2}{|l|}{ Anterior } & \multicolumn{8}{|l|}{ Posterior } \\
\hline & $\begin{array}{l}0 \\
\text { Iron-loaded }\end{array}$ & $\begin{array}{l}0 \\
\text { Control }\end{array}$ & $\begin{array}{l}24 \\
\text { Iron-loaded }\end{array}$ & $\stackrel{24}{\text { Control }}$ & $\stackrel{48}{\text { Iron-loaded }}$ & $\begin{array}{c}48 \\
\text { Control }\end{array}$ & $\begin{array}{l}72 \\
\text { Iron-loaded }\end{array}$ & $\begin{array}{c}72 \\
\text { Control }\end{array}$ & $\begin{array}{l}264 \\
\text { Iron-loaded }\end{array}$ & $\begin{array}{c}264 \\
\text { Control }\end{array}$ \\
\hline $\begin{array}{l}\text { No. of rats } \\
\text { Mean }(\%) \\
\text { Standard error } \\
\text { P } \\
\text { P }\end{array}$ & $\begin{array}{l}18 \\
\begin{array}{l}29.6 \\
\pm 0.2 \\
\\
\quad \pm 2.9 \\
0.01>P\end{array}\end{array}$ & $\begin{array}{l}18 \\
28 \cdot 7 \\
\pm 0.22 \\
1 \\
>0.001\end{array}$ & $\begin{array}{l}5 \\
7.87 \\
\pm 0.33 \\
\pm 1 . \\
0.1>\mathrm{P}\end{array}$ & $\begin{array}{l}6 \\
6.65 \\
\pm 0.43 \\
84^{ \pm 0.05}\end{array}$ & 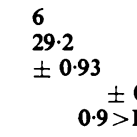 & $\begin{array}{l}\frac{5}{29 \cdot 6} \\
\pm 1 \cdot 15 \\
202 \\
>0.8\end{array}$ & 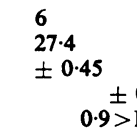 & 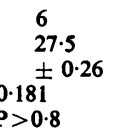 & 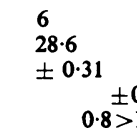 & 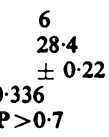 \\
\hline
\end{tabular}

${ }^{1}$ Dry weight is expressed as a percentage of wet weight.

TABLE III

INCIDENCE OF MITOSIS PER 1,000 CELLS

\begin{tabular}{|c|c|c|c|c|c|c|c|c|c|c|}
\hline \multirow{2}{*}{$\begin{array}{l}\text { Lobes } \\
\text { Time }(h r .) \\
\text { Group }\end{array}$} & \multicolumn{2}{|l|}{ Anterior } & \multicolumn{8}{|l|}{ Posterior } \\
\hline & $\begin{array}{l}0 \\
\text { Iron-loaded }\end{array}$ & $\begin{array}{l}0 \\
\text { Control }\end{array}$ & $\begin{array}{l}24 \\
\text { Iron-loaded }\end{array}$ & $\begin{array}{l}24 \\
\text { Control }\end{array}$ & $\begin{array}{l}29 \\
\text { Iron-loaded }\end{array}$ & $\begin{array}{l}29 \\
\text { Control }\end{array}$ & $\begin{array}{l}48 \\
\text { Iron-loaded }\end{array}$ & $\begin{array}{l}48 \\
\text { Control }\end{array}$ & $\begin{array}{l}72 \\
\text { Iron-loaded }\end{array}$ & $\begin{array}{l}72 \\
\text { Control }\end{array}$ \\
\hline $\begin{array}{l}\text { No. of rats } \\
\text { Mean } \\
\text { S.E. } \pm \\
t \pm \\
\text { P }\end{array}$ & $\begin{array}{l}6 \\
0 \cdot 23 \\
0 \cdot 15\end{array}$ & $\begin{array}{l}6 \\
0 \\
0\end{array}$ & $\begin{array}{c}6.5 \\
<0.001\end{array}$ & $\begin{array}{l}6 \\
0 \cdot 68 \\
0 \cdot 15\end{array}$ & $\begin{array}{lr}5 & \\
26.8 & \\
6.9 & \\
& 4.2 \\
& <0.01\end{array}$ & $\begin{array}{l}6 \\
13 \cdot 3 \\
3 \cdot 0\end{array}$ & $\begin{array}{lr}6 & \\
6 \cdot 7 & \\
2 \cdot 7 & \\
& 0 \cdot 16 \\
& 9>P>\end{array}$ & $\begin{array}{l}5 \\
7 \cdot 0 \\
1 \cdot 7 \\
\cdot 8\end{array}$ & $\begin{array}{lr}6 & \\
2.6 & \\
0.41 & \\
& 1.0 \\
& .4>P>\end{array}$ & 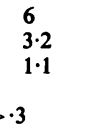 \\
\hline
\end{tabular}

at $24,48,72$, and 264 hours is given. The anterior lobes of the liver of the iron-loaded rat have a slightly reduced water content, dry weight being $29.7 \% \pm 0.2$ of wet weight as against $28.7 \% \pm 0.22$ of the control rats; the difference is significant $(\mathrm{t}= \pm 2.910 .01>\mathrm{P}>0.001)$. No significant difference could be found between the water content of the regenerated livers of the iron-loaded and normal rats at $24,48,72$, or 264 hours after partial hepatectomy so the wet weights in Table I have not been corrected for variation in dry weight.

Incidence of mitosis Partial hepatectomy is followed after a latent period of about a day by the appearance of mitotic figures in the regenerating posterior lobes. The maximal incidence of mitoses has been found at 28 or 29 hours (Weinbren, 1959). In Table III the mean incidence of mitoses per 1.000 cells is given for the anterior lobes removed at partial hepatectomy, and for the posterior lobes 24 , 29,48 , and 72 hours after partial hepatectomy in iron-loaded and control rats. The finding of mitotic figures in the resected anterior lobes of iron-loaded rats but not in the controls suggests that iron loading itself results in an increase in mitotic activity. Following partial hepatectomy the number of mitotic figures at $\mathbf{2 4}$ hours is more than ten times as great in the iron-loaded rats $(7.9$ per 1,000$)$ compared with the controls $(0.68$ per 1,000$)$, and at 29 hours the incidence of mitosis is significantly greater in the iron-loaded rats $(26.8$ per 1,000$)$ compared with controls (13.3 per 1,000), but thereafter the incidence of mitosis is the same in the two groups. The maximal incidence of mitosis found in the control rats at 29 hours, $13 \cdot 3$ per 1,000 cells, is about a third to a half the incidence found by 
Weinbren (1959). The lower incidence found in these experiments may be accounted for by the fact that the rats were killed between 7 p.m. and 10 p.m. when the normal diurnal variation in mitosis would result in a lower incidence (Jaffe, 1954).

MICROSCOPIC CHANGES IN THE REGENERATING LIVER Following the administration of iron-dextran much of the iron is present in the Kupffer cells, aggregates of iron-containing cells being present in the portal tract and adjacent to the central vein (Golberg et al., 1957). In addition the parenchymal cells also contained considerable amounts of iron.

Regeneration of the liver is associated with an alteration in the normal pattern of liver cell plates; this occurred equally in the two groups. There was no evidence of cell necrosis, of fibrosis, or of change in overall liver architecture following regeneration in either group. Regeneration of the liver in the ironloaded rat was occasionally accompanied by round cell infiltration of the portal tracts; none was found in the controls. Apart from the presence of the iron there was no difference in the architecture of the liver between the iron-loaded and control rats killed 12 weeks after partial hepatectomy. During mitosis of the iron-laden liver cell the iron granules are most often displaced to the poles of the cell, but not infrequently iron-staining granules seem to be between the chromosomes in the anaphase. However, no abnormal mitotic figures were observed.

\section{DISCUSSION}

The results of the experiments suggest that despite the presence of large amounts of iron in the Kupffer and parenchymal cells the growth of the liver immediately following partial hepatectomy is relatively unaffected. The hypertrophy of the liver produced by the iron makes a direct comparison of the weights of the regenerating liver in the two groups impossible. When the increase in weight of the regenerating liver is expressed as a proportion of the calculated initial weight, the initial phase of growth of the posterior lobes is the same in the two groups. But by 11 days the growth of the iron-loaded rats is less than the controls when compared on this basis; however, by this time the actual weights of the regenerating liver in the two groups are very similar. By 12 weeks the weight of the regenerated liver is less in the iron-loaded rats than in the controls. The number of rats killed at this time was small. However, the findings at 11 days and 12 weeks suggest that there may be some impairment of growth of the iron-loaded livers. There were no histological abnormalities to account for this impression apart from the presence of the iron.
More striking differences were found in the incidence of mitosis in the two groups. Whereas no mitotic figures were found in the resected anterior lobes in the control rats, occasional mitotic figures were present in the iron-loaded rats. Following partial hepatectomy many mitotic figures were found in iron-loaded rats at 24 hours, and the number at 29 hours was greater in the iron-loaded rats than in the controls. The proportion of cells showing mitotic figures at any one instant is dependent on two factors: the actual number of cells in which mitosis is induced and the duration of mitosis in the individual cells. An increased incidence of mitosis after partial hepatectomy has been observed following the administration of nitrogen mustard, the apparent increase being due to a slowing down of the process of mitosis (Landing, Seed, and Banfield, 1949). Since the sensitivity of the iron-loaded rat to ethionine, or vitamin E deficiency is considered to be due to oxidation of essential sulphydryl groups by the accumulated intracellular iron (Golberg and Smith, 1960), and as sulphydryl groups play an important role in mitosis (Swann, 1957), it is possible that iron might have a direct effect on the process of mitosis. However, such an effect would in all probability result in a slowing of mitosis, the action being akin to that of nitrogen mustard. If this were so the peak of mitosis should occur later in the iron-loaded animals than in the controls. The finding of a higher incidence of mitosis in the iron-loaded rats at 24 and 29 hours, but not at 48 or 72 hours, suggests that there is an accelerated response to partial hepatectomy rather than a slowing of the process.

Studies of cell division have shown that there is a period of cell growth before mitosis can occur, which is responsible for the delay between the stimulus to mitosis and the occurrence of the maximal incidence in a cell population (Swann, 1957). The hypertrophy of the liver produced by the iron may have resulted in a greater proportion of cells having achieved an essential pre-mitotic phase of growth, thus shortening the interval between the stimulus of partial hepatectomy and the occurrence of mitosis.

The results of these experiments suggest that the accumulation of excess iron in the liver results in an increased rate of cell division in the liver. A somewhat similar response has been shown to follow the accumulation of fat in the liver cells of rats on a choline-deficient diet, an increase in mitosis being observed before the development of cirrhosis (MacDonald, Schmid, and Mallory, 1960). Partial hepatectomy may, therefore, reveal a latent growth which becomes apparent as an earlier and greater incidence of mitosis following the operation. Although the toxic effects of iron are thought to be 
due to its ability to oxidize sulphydryl groups which are known to play an important role in mitosis, it seems unlikely that the iron in the parenchymal liver cell has any direct effect on mitosis. It is possible, however, that the progressive accumulation of iron in the liver by increasing the rate of cell division may render the liver cell more susceptible to factors influencing mitosis.

The occurrence of iron loading of the liver in human subjects is the result of a long period of increased iron absorption or of the progressive accumulation of iron from repeated blood transfusions. It seems probable that the continued accumulation of iron in the liver cell may increase the rate of cell division. The experiments reported here make it unlikely that the presence of the iron by itself affects such cell division. Thus the development of cirrhosis in such subjects is probably related to other factors than the ability of the parenchymal liver cell to undergo mitosis.

I am grateful to Professor I. Doniach for encouragement and for providing facilities for the experiments and to Dr. K. Weinbren for advice and for reading the manuscript. I am indebted to Mr. D. Tills and to Mr. A. Weir for assistance with the animals, and to Mr. E. G. Hamilton and the histological laboratory of the Department of Morbid Anatomy for the preparation of the histological material.

\section{REFERENCES}

Aufderheide, A. C., Horns, H. L., and Goldish, R. J. (1953). Secondary hemochromatosis. I. Transfusion (exogenous) hemochromatosis. Blood, 8, 824-836.

Bothwell, T. H., Cohen, I., Abrahams, O. L., and Perold, S. M. (1959) A familial study in idiopathic hemochromatosis. Amer.J. Med., 27, 730-738.

Brown, E. B., Moore, C. V., Reynafarje, C., and Smith, D. E. (1950). Intravenously administered saccharated iron oxide in the treatment of hypochromic anemia; therapeutic results, potential dangers and indications. J. Amer. med. Ass., 144, 1084-1089.
Cappell, D. F. (1930). The late results of intravenous injection of colloidal iron. J. Path. Bact., 33, 175-196.

- Hutchison, H. E., and Jowett, M. (1957). Transfusional siderosis: the effects of excessive iron deposits on the tissues. Ibid., 74, 245-264.

Finch, S. C., and Finch, C. A. (1955). Idiopathic hemochromatosis, an iron storage disease. Medicine (Baltimore), 34, 381-430.

Golberg, L., and Smith, J. P. (1960). Iron overloading and hepatic vulnerability. Amer. J. Path., 36, 125-149.

_prolonged administration of iron parenterally in animals. Brit. J. exp Path., 38, 297-311.

Harkness, R. D. (1952). Changes in the liver of the rat after partial hepatectomy. J. Physiol. (Lond.), 117, 267-277.

Higgins, G. M., and Anderson, R. M. (1931). Experimental pathology of the liver; restoration of the liver of the white rat following partial surgical removal. Arch. Path., 12, 186-202.

Jaffe, J. J. (1954). Diurnal mitotic periodicity in regenerating rat liver. Anat. Rec., 120, 935-954.

Landing, B. H., Seed, J. C., and Banfield, W. G. (1949). Effects of a nitrogen mustard on regenerating rat liver. Cancer (Philad.), 2, 1067-1074.

Lawrence, R. D. (1935). Haemochromatosis and heredity. Lancet, 2 1055-1056.

MacDonald, R. A. (1960). Experimental pigment cirrhosis. Amer. J. Path., 36, 499-519.

- (1963). Idiopathic hemochromatosis: genetic or acquired. Arch. intern. Med., 112, 184-190.

- and Mallory, G. K. (1960). Hemochromatosis and hemosiderosis; study of 211 autopsied cases. Ibid., 105, 686-700.

-, Schmid, R., and Mallory, G. K. (1960). Regeneration in fatty liver and cirrhosis: autoradiographic study using tritiated thymidine. Arch. Path., 69, 175-180.

Nissim, J. A. (1953). Experimental siderosis: a study of the distribution delayed effects and metabolism of massive amounts of various iron preparations. J. Path. Bact., 66, 185-204.

Polson, C. (1933). The failure of prolonged administration of iron to cause haemochromatosis. Brit. J. exp. Path., 14, 73-76.

Rather, L. J. (1956). Hemochromatosis and hemosiderosis. Does iron overload cause diffuse fibrosis of the liver? Amer. J. Med., 21, 857-866.

Rous, P., and Oliver, J. (1918). Experimental hemochromatosis. J. exp. Med., 28, 629-644.

Schwartz, S. O., and Blumenthal, S. A. (1948). Exogenous hemochromatosis resulting from blood transfusions. Blood, 3, 617-640.

Sheldon, J. H. (1935). Haemochromatosis. Oxford University Press, London.

Swann, M. M. (1957). The control of cell division: a review. I. General mechanisms. Cancer Res., 17, 727-757.

Weinbren, K. (1959). Regeneration of the liver. Gastroenterology, 37, 657-668.

- Fitschen, W., and Cohen, M. (1960). The unmasking by regeneration of latent irradiation effects in the rat liver. Brit. J. Radiol., 33, 419-425.

Williams, R., Scheuer, P. J., and Sherlock, S. (1962). The inheritance of idiopathic haemochromatosis. Quart. J. Med., 31, 249-265.

Witzleben, C. L., and Chaffey, N. J. (1962). A study of iron-induced liver damage. J. exp. Med., 115, 723-729. 